\title{
Educational Philosophy as Social Agent of Changes
}

\author{
HM. Zainuddin \\ Universitas Negeri Malang,Malang, Indonesia \\ e-mail: zainuddinpgsd57@,gmail.com
}

\begin{abstract}
Education is the institution that can be functioned as the agent of social reformer or social changes as well as determine the direction of the social changes namely social development. Every social changes occur in society can be planned based one the direction of changes to be achieved. An educator needs to understand the streams of philosophy of education in order to take advantages from these streams in doing the role as educator. The occurrence of social changes is driven by the progress of intelligence in discovering science and technology in which delivered spectacular changes in the way of life. The occurrence of such changes that took place subsequently commonly accepted as part of educational progress. The education world must posit itself as an agent of changes. Education that is only intended to educate the brain must be transformed into a holistic perspective is that to educate the behavior as a whole. Education must be able to construct a cultural identity for human beings.
\end{abstract}

Keywords: educational philosophy, social changes

\section{INTRODUCTION}

Education and social changes are interrelated each other. Both of them influence each other so that widely affect in society. Education is the institution that can be functioned as the agent of social reformer or social changes as well as determine the direction of social changes namely social development. Every social changes that occur in society can be planned based one the direction of changes to be achieved. However, social changes can also occur without being planned previously as the effect of outside culture influence.

Education since then until nowadays is the most important thing in human's life. Education provides human thought progress, so that their standard of life is increase. In its development, dayto-day education changes into a system. A system of education is constructed systematically and then it is regulated into The Law of Republic of Indonesia number 20 year 2003 about The Law of National Education System Article 11 paragraph 1 which states that education, is conducted through three streams, they are formal, non-formal, and informal education. These third education streams are interconnected one to other and they are needed to do social changes that occur in the future society. Instate of these third education streams, children in Indonesia must take education is that "9 year compulsory education", as a government program in improving the human resources of Indonesian.

Education affects to the society and finally social changes occur. Social changes represent innovation deals with all aspects of human's life that aims to increase prosperity. Various concepts deal with social changes have been proposed by experts to analyze the phenomenon that is, the concept of social progress, socialistic concepts, the concept of cyclical change, historical theory, particularistic theory, sociology theory and sociology and social changes.

Based on the description above, this article aimed at explaining about educational philosophy as an agent of social changes. 


\section{LITERATURE REVIEW}

\subsection{Educational Philosophy}

\subsubsection{Definition}

Subekti, Sri. 2015 stated that similar with philosophy in general, educational philosophy is a speculative, prescriptive, and analytical thing. Educational philosophy is speculative when it posits to discover certain theory dealing with basic characteristic of human and community to explain the conflict of results of an educational and social science research. Educational philosophy is prescriptive when educational philosophy sets goals of education to be obeyed and achieved.

Educational philosophy is analytical when it is functioned to clarify speculative and prescriptive statements. An analyst, as we know, examines the rationality of educational ideas, consistency with other ideas, and examines the deviations. An analyst examines the logic of the concepts and their deficiencies into an inexplicable product. In addition, an analyst also clarifies the different notions that have been used in such educational terms, such as "freedom", "adjustment", "development", "experience", "need", and "knowledge". We are now ready to accept the various branches of philosophy, especially metaphysics, which are strongly related to education.

\subsubsection{The Implementation of Educational Philosophy}

Philosophers have different systems of thought in describing the four eternal problems, namely the nature of the existing, the nature of knowledge, the nature of values, and human nature. Therefore, there are various specific streams for each philosopher, such as Socrates and Plato with "Idealism", Aristoteles "Realism", John Dewey known with the flow of "Pragmatism", Soren Kierkegaard exist with the flow of "Existentialism", and so forth. Furthermore, these four eternal problems are used to interpret and implement philosophy in education. The question is why education uses a philosophical thought approach. Education is a field of study both theoretically and practically cannot be released with life problems, especially problems of the purpose of life, value problems, personal development issues, and truth / knowledge issues. So, every education which is implemented in certain country will describe how philosophical view of those country. In line with the above description, the philosophical view of Indonesian is that "Pancasilais" should be implemented into educational practices in family education, school as well as in society education. Furthermore, we will examine more about the schools of educational philosophy in relation to the outcome of the study of educational philosophy, and its usefulness to those engaged in the world of educational professionalism.

Subekti, Sri (2015) suggested that (1) an educator needs to understand the schools of educational philosophy in education because it has the benefit of carrying out the role of educator where the benefits in life are the basic fundamentals in making decisions, acting, reducing misconceptions and conflicts, preparing for the world situation which always change. (2) An educator does not have to be a follower of a particular school, but she/he can use the schools of philosophy in an eclectic way, because the educational situational choice of the philosophy should be done carefully and should be selected for reasons of positive value and in accordance with norms and religions that relevant with society's view.

\subsection{Social Change}

\subsubsection{Definition}

Social change is a process that encompasses the overall form of aspects of people's lives. According to observations, social change has become a point of study of diverse disciplines. Social change is a matter of social theories used to illuminate the phenomenon of social change unilaterally. In many ways, theory, substance, and methodology cannot be separated into a system of thinking to understand the phenomenon of complete social change.

Social change describes a process of community development. On the one hand, social change provides a characteristic of progress but on the other hand, it can also be a regress. Social change can occur because of a natural cause and a planned cause. A natural social change is a change that comes from within society itself. Meanwhile, the planned social change is a change that occurs because of a planned program, often in the form of intervention, which originated from within or from outside a community. The planned change coming from within the community is often a program of change made by a particular group of community 
members, usually community elites, directed against other community groups.

The phenomenon of social change that is still relevant with current life is a modernization phenomenon that proclaimed the Western to improve the economy of the people in third world countries. The impact of modernization is vast, both considered positive and negative by society in third world countries, whether related to economic, social, political, cultural and scientific issues. Modernization as a phenomenon of change received a variety of responses, even criticized as westernization. After all, a society is not an empty vessel that simply receives things that come from outside, but it has a certain mechanism through the norms and values of tradition (culture) in dealing with and responding to the changes that take place.

In this regard, the roles of change agents (government and community institutions) are able to anticipate the various development of society so that they are able to lead the society to change to a better direction.

\subsubsection{The Aspects of Social Change}

Sociology study is distinguished into macro sociology and micro sociology. Macro sociology is the science of sociology that studies large-scale social patterns especially in comparative and historical terms, for example between specific societies, or between particular nations. Micro sociology is more concerned with social behavior in certain groups and social settings. Driven by these definitions, it is difficult to put the study of social change, whether in the position of macro or micro sociology. However, by considering several aspects, as will be explained later, the study of social change has a double face, both macro and micro sociology.

However, formulating a concept or definition that can be accepted by various parties is a difficult job and may not be useful. So that, in this study the theory of social change put forward does not pretend to satisfy a number of demands. In this study, a definition of social change is a change from one condition to another by looking at it as a symptom caused by various factors. It happens more as the "back and forth" dynamics between human nature and capability as living creatures and possesses certain abilities (internal factors) of dialogue with their natural (physical), social, and cultural environments (external factors).

The issues discussed by the theory of social change are as follows. First, how the speed of a change takes place, in which direction and form of changes, and how the barriers are. In the case of Indonesian society, social change can be done by looking at the history of social development. Indonesia experienced the process of acceleration of development, or early modernization, especially after the 1900s, when the Dutch introduced the policy of ethical politics. However, as will be explained later, the acceleration of change in Indonesia mainly occurred after the 1980 s. It is related to the mutual influence of the development of science and technology as well as some of the convenience caused by the practice.

Second, factors influence toward social change. There are six factors influencing social change, they are (1) information dissemination including affect and mechanism media in delivering messages or idea (thought); (2) capital, such as human resources or financial capital; (3) technology, an element as well as a factor that quickly changes with the development of science; (4) ideology or religion, how a particular religion or ideology influences the social change; (5) bureaucracy, especially in relation to certain government policies in building its power; and (6) agents or actors. This generally includes in the human capital, specifically intended to individual initiative in discovering better life

Third, source of the change takes place, from the state, or from the free market (foreign power), or even from within the society itself. Fourth, what things change and how that change takes place. Change can be something that is physical (visible/ material), such as the occurrence of development in the physical sense, but there are also things that are not visible (nonmaterial), such as thinking, awareness, and so forth. Fifth, what things or discourses are dominant in the process of social change? For example, for the case of Indonesia among the six factors of change as mentioned above, which of them is dominant, and why it happens.

Sixth including how to distinguish the changing contexts in each society, and how the social process takes place. In this case, first, there is reproduction process, which is the process of repetition in different times and spaces as well as the social and cultural heritage of the previous society. Second is transformation, a new process of change of form or creation, or different from before.

\subsubsection{Type of Social Change}

The direction of social change in Indonesia seems not to be determined carefully enough. The process of bargaining is still happening, and 
everything is still very likely. However, for sure, until now the people of Indonesia are still anxious, angry, sad, and concerned. Democracy is still striving for, and not knowing what kind of democracy is going to happen, law enforcement is still confusing, and relatively people live without certainty (Salam: 2007). In general, forms of sociocultural change can be divided into two: the first is the changes that take place quickly and concerning the basic or basic life of the people called the revolution. In the revolution, the changes that occur can be planned or unplanned in advance and can be run without violence or through violence.

The speed of a change is actually relative because the revolution can take a long time. For example, the industrial revolution in Britain that takes decades, but it is considered 'fast' because it is able to change the basic joints of community life such as the family system and the relationship between workers and employers - which has been going on for hundreds of years. The revolution requires an attempt to knock down, break down, and build from the old system to an entirely new system. Revolution is always associated with dialectics, logic, romance, breaking, and building.

The second is the change takes place within a certain period of time (slow) called evolution. In the context of modern biology, evolution means the change of inherited traits in a population of organisms from one generation to the next. Second, change takes place within a certain period of time (slow) called evolution. In the context of modern biology, evolution means the change of inherited traits in a population of organisms from one generation to the next. Genes that are inherited to the offspring of a living being carry the basis traits of this evolution. New traits can be obtained from gene changes by mutations, gene transfer between populations, such as in migration, or between species as occurs in bacteria, as well as combinations of genes through sexual reproduction. However, the theory of evolution has always been associated with Charles Darwin, evolutionary biology has actually taken root since the time of Aristotle. Nevertheless, Darwin was the first scientist to propose a theory of evolution that has proven to be well established in scientific testing. Right now, Darwin's theory of evolution by natural selection was regarded as the best theory in explaining the evolution.

Social change includes complex aspects such as politics, economics, culture, law, safety and so on. Changes that occur, either quickly or slowly will have an impact on society, as well as education.
Rapid change (revolution) is generally more likely to shock the public so unprepared for the change.

\subsection{Education Philosophy As A Social Change Agent}

George S Counts argues that education will play a role if schools become the new center of community development as a whole, eradicating poverty, war, and ethnical. People suffering from economic hardships and big social problems are a challenge for education to play its role as an agent of reform and social reconstruction. The goal of education is to foster educated awareness related to the social, economic, and political problems facing humans on a global scale and to give them the skills to have the ability to solve those problems. The ultimate goal of education is the creation of a new society, a global society of interdependence.

Reconstructionist education theory by Brameld (Widyaprimaswari, 2014) is that education should be implemented in order to create a new social order that will fill our basic cultural values and in harmony with the underlying economic and social forces of modern society. Now civilizations face the possibility of self-destruction. Education must support the correct change in the human conscience. So great technological power must be used to build humanity, instead of destroying it.

\subsection{The Relationship Of Educational Philosophy Toward Social Change}

The National Education Policy is still managed with positivism approach. In some macro studies, educational issues will always generate parameters in the form of student flows, the number of participants for a certain level and type of education such as the number of drop out, average achievement of NEM, and others. Educational problems in the educational community finally seem to be technically impressed, so the solution is highly dependent on the provided mechanical treatments. For example, the problem of quality improvement of education will always get help teacher training facilities, the addition, and improvement of school equipment, and so forth. Educational issues are rarely observed in government institutions and community institutions in an effort to improve the usefulness of education. Educational issues seem to have never 
been researched as the forces of social ideology possessed by great power in society. It driven due to the educational process is never realized as a power that is always used by many interests in overlap.

Social change as it appears in its tendencies from time to time, can occur like the wild phenomenon of other natural phenomena, in which human beings as natural creatures are faced with various demands of life as nature changes, and social history. The facts include human exploitation by humankind to the nation over other nations and the general tendency of human use of natural resources arbitrarily. This real history cannot be denied and therefore continues until somehow.

The social changes that have been driven by the progress of intelligence in discovering science and technology have led to spectacular changes in the way of life. The occurrence of changes that took place subsequently may be broadly accepted as part of educational progress. The development of science and technology was originally the result of research at the university, although later university research became far behind by the business competition developed by the corporate world. Education, at least have a role in transforming the foundations and findings Science and Technology into the hands of humans. Education, however, becomes mindless instrumentation when it is created and developed by the technical interests of humans in taking control of the livelihood as well as children. As a result, social changes that occur more provide negative access, and distanced from the noble purpose of life as a human being. If from a long history, we know only defeat in the eyes of the world until now. Education is an investment to reach the future victory. Ignoring education is tantamount to allowing this nation not to know how to deal with its future, and that is as great as a crime against humanity and its own nation.

In order to achieve the expected change for a nation, education development becomes the key word. According to Kuntowijoyo (1997) there are three stages with regard to the change of society: First, the dual phase of society, when there is a need for separation between the civil society and the political society or between the people and the state. Because of this election, the state does not provide services and protection in accordance with the needs of the community. The two stages of a single society, namely when civil society has been successfully established, and third, the ethical society stage which is the final stage of the mining "(Widyaprimaswari, 2014).
Theoretically, society is formed by the consciousness. The state is constructed by interests and awareness of society, and interests to the state as well. If it is stretched over the agreed upon values, as set forth in the basis and purpose of the state, which actually reflects the noble ideals, the culture of society. In addition, this nation is strong Moslem. It does not have to be a significant constraint in researching development towards the change expected. Therefore, society and state as institutional constructions are required to build synergic relationships, through mutual gait to bring the nation's children and the fate of their future, except with education no other way. Because of the change we expect is a change towards improving the quality of life, we do not want unbridled changes like crises and disasters. Changes towards quality improvement are only possible if the nation is able to learn intelligently to address the ever-present demands. It is impossible to achieve without education.

Thus, education and social change are an inseparable unity in which education always exists in society at a modest level though. There are two or more individuals continuously interact and persistence as a community, education is born by itself. First, as part of the instinct, but the everincreasing challenges of human life have, provided learning experiences ranging from empirical invention to ability outcomes Reflection of the power of reason and mind. Furthermore, as one of the results of development that is running continuously, the results of education encourage social change, moreover social change itself was born by bad experience collective done by the tendency of many people in society.

\section{CONCLUSION AND SUGGESTION}

The social changes that have been driven by the progress of intelligence in discovering science and technology have led to spectacular changes in the way of life. The occurrence of such changes that took place subsequently en masse may be accepted as part of educational progress.

The world of education must posit itself as the agent of change. The education that is only intended to educate the brain must be transformed into a holistic perspective to educate the whole behavior. Education must be able to construct a cultural identity for human beings. Our culture is a pluralistic culture. 


\section{REFERENCES}

[1] Subekti, Sri. 2015. Artikel Filsafat Pendidikan.(online),

(http://dokumen.tips/documents/artikel-

filsafat-55a4d20ae9016.html), diakses pada 1 Mei 2016.

[2] Syafitriyah, Nur. 2014. Pengaruh Perubahan Sosial. (online), (http://nursyafitriahcellow.blogspot.co.id/2014/ 08/makalah-pengaruh-perubahan-sosial.html), diakses pada 1 Mei 2016.

[3] Widyaprimaswari. 2014. Pendidikan Sebagai Agen Perubahan Sosial dan Pelestarian Nilai. (online),

(http://widyaprimaswari.blogspot.co.id/2014/0 7/pendidikan-sebagai-pelestarian-nilai.html), diakses pada 1 Mei 2016. 